\title{
Relationship between soil physicochemical characteristics and nitrogen-fixing bacteria in agricultural soils of the Atlántico department, Colombia.
}

\section{Abstract}

\author{
Martínez-Mera Eliana Andrea $^{l^{*}}$, Torregroza-Espinosa Ana Carolina ${ }^{1}$, Valencia-García Anderson ${ }^{I}$, \\ and Rojas-Gerónimo Laura'. \\ ${ }^{1}$ Universidad de la Costa CUC, Facultad de Ingeniería, Barranquilla, Colombia
}

\begin{abstract}
Microbial richness of agricultural soils is an indicator of its health and fertility with a significant impact on crop yields. Present study analyzed the relationship between nitrogen-fixing bacteria and physicochemical characteristics of agricultural soils in the southern department of Atlántico, Colombia. Soil samples were collected from 10 sites of Repelón irrigation district, for physicochemical analysis ( $p H$, organic matter, texture, moisture and available phosphorus) and isolation of nitrogen-fixing bacterial'strains using nitrogen-free culture media. Results demostrated the higher previlance of nitrogen-fixing bacteria in northern zone and central zone of the Repelon irrigation district $\left(1.63 \times 10^{8} \mathrm{CFU} \mathrm{g}^{-1}\right.$ for strain-1, $5.2 \times 10^{7} \mathrm{CFU} \mathrm{g}^{-1}$ for strain-2 and $4.5 \times 10^{7} \mathrm{CFU} \mathrm{g}^{-1}$ for strain3). On the other hand, the physicochemical characteristics of soil show the adequacy to sustain nitrogen-fixing bacteria. The findings of the present research may serve as a baseline to identify soil micorganisms and defining strategies for sustainable management of agricultural soils in the region because these are integral component in ecosystem for nutrient recycling.
\end{abstract}

Keywords: Native microorganism, fertilization, sustainable management, conservation.

\section{Introduction}

In agriculture, nitrogen is the principal nutrient for plant growth (García, 2011) and productivity. Nevertheless, nitrogen mineralization is very slow process ( 1 to $3 \%$ of the total $\mathrm{N}$ of the soil) (Escobar et al., 2011). In nitrogendeficient soils, it is necessary to use nitrogenous fertilizers to increase yield of the crops. However, indiscriminate use of these fertilizers and losses after their application (through erosion, leaching and volatilization) can cause serious soil contamination problems. These problems are mainly related to the increase in soil salinity, decrease in soil $\mathrm{pH}$ (mostly of nitrogenous fertilizers exert an acidifying action on the soil), and the contamination of groundwater (MartínezMera et al., 2016; Iturri and Buschiazzo, 2016). At the same time, these alterations in the physicochemical characteristics of soils, depending on the climatic conditions of the zone, can bring changes in the distribution, diversity and abundance of soil microorganisms (Mahmood et al., 2006; Gupta and Roper, 2010). The identification of alternative sources of fertilization that reduce impacts on soils is necessary for the development of sustainable agriculture and sustainable soil management practices (Martínez-Mera et al., 2016).

Nitrogen-fixing bacteria are among important microorganisms in agricultural soils which are recognized free-living or non-symbiotic (e.g. Clostridium, Beijerinckia, and Azotobacter genera) and mutualistic or symbiotic (e.g. genera of Rhizobium,
Frankia, and certain species of Azospirillum) associated with different species of plants. Nitrogen-fixing bacteria are prominent because of their capability to transform inert nitrogen from atmosphere into bioavailable form for plants (Philippot and Germon, 2005). Biological nitrogen fixation is critical for ecosystem productivity (Dahal et al., 2017). In addition, these bacteria have the ability to promote plant growth through synthesis of plant growth regulating hormones (e.g. indole acetic acid), inhibition of growth of plant pathogens and decrease in incidence of disease through secretion of antibiotic like substances and increase in $\mathrm{P}$ nutrition through phosphates solubilization (Escobar et al., 2011).

In order to promote the establishment of sustainable agricultural systems, it is necessary to have a fundamental knowledge of different components that comprise it (Ferrera and Alarcón, 2001). In Colombia, few studies have been carried out on this subject (e.g. Mantilla-Paredes et al., 2009), particularly agricultural areas in the south of Atlántico department. Qualitative and quantitative information concerning soil microflora is very scarce and there are no reports on this aspect. Thus, it is necessary to generate information on the health of agricultural soils of the south of Atlantico department represented by populations of nitrogen-fixing bacteria. Finally, this research may serve as a baseline to define strategies for sustainable management of agricultural soils of south Colombian region.

\footnotetext{
*Email: emartine40@cuc.edu.co
} 


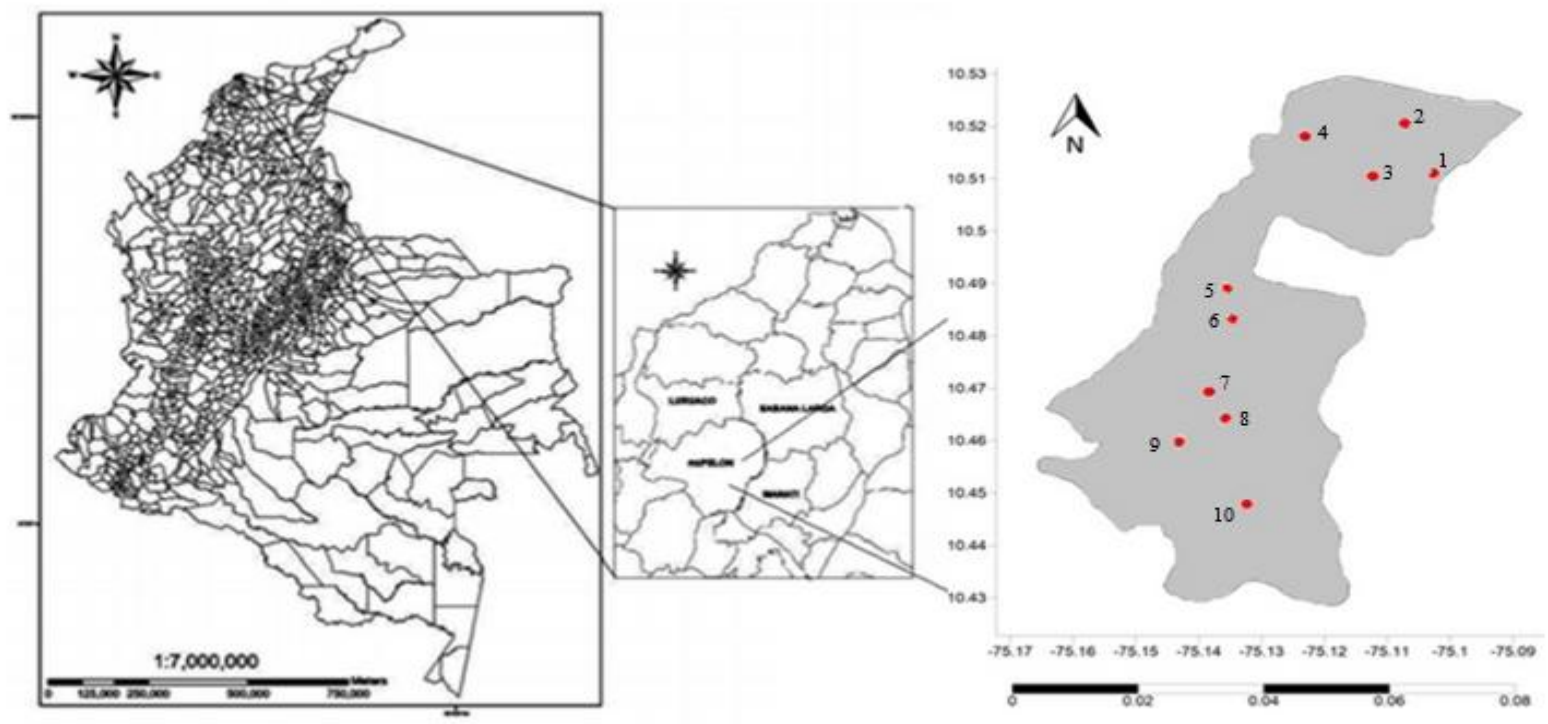

Figure 1. Location of the Repelón Irrigation District (Modified by Torres-Bejarano et al., 2016).

The study was carried out in agricultural soils of the Irrigation District of Repelón ( $10^{\circ} 29$ ' $\mathrm{N}$ and $\left.75^{\circ} 08^{\prime} \mathrm{O}\right)$ located south of Atlántico department, Colombia (Figure 1). The Irrigation District of Repelón records an average annual temperature of $28.2^{\circ} \mathrm{C}$. The annual precipitation varies and dry season is characterized by average rainfall of $39 \mathrm{~mm}$ (January to July), and rainy season gives $117.2 \mathrm{~mm}$ rainfall that extends from August to December (Climate, 2017). The soils belong to the order inceptisols, subgroups Fluventic Haplustepts and Typic Haplustepts (IGAC, 2008). Sampling was carried out in June 2016 i.e during dry season. Sampling sites were selected at random and collected soil samples were named according to characteristics zone beginning in the north to the south of irrigation district. At each sampling site, a plant was taken as axis and at $1 \mathrm{~m}$ distance, three points were established. At each point the vegetation cover was removed and deepened to $20 \mathrm{~cm}$. Composite soil samples were prepared by mixing the three sub-samples to get representative soil sample for each site (IGAC, 2006). The samples were stored in Ziploc ${ }^{\circledR}$ bags and transported in polyethylene coolers with gel packs, maintaining a temperature of $2 \pm$ $1^{\circ} \mathrm{C}$. These samples were maintained under these conditions for $24 \mathrm{~h}$, till processing initiated.

A portion of each sample was stored for the determination of potential nitrogen-fixing bacterial population and another part for physicochemical analyses. All analysis were carried out in the Microbiology and Environmental laboratories of the University of the Costa CUC. The physicochemical parameters evaluated were: $\mathrm{pH}$, humidity, organic carbon (Walkley and Black, 1934) to calculate organic matter and total phosphorus (Olsen et al., 1954) (IGAC, 2006). Soil texture was evaluated with Bouyoucos-Densimeter Hydrometer, IGAC method adapted to Colombian soils at certified laboratory.

On the other hand, during the sampling, the study area was surveyed and primary information was collected through interviews with farmers about the agricultural practices. They were asked about general aspects about crop production practices such as area planted, type of crop frequency of pests and use of fertilizers and pesticides (type of pesticide or fertilizer, characteristics, amount applied, method and frequency of application).

For the isolation of nitrogen-fixing bacterial strains, Nselective culture media as asbhy mannitol agar, congo red agar and yeast extract mannitol agar, were used. Ten grams of composite sample (inoculum) was used to prepare $\left(10^{-1}\right.$ to $\left.10^{-5}\right)$ dilutions. Fifty microliters $(50 \mu \mathrm{L})$ aliquots of three dilutions $\left(10^{-3}, 10^{-4}\right.$ and $\left.10^{-5}\right)$ were seeded into each of the culture media. For each dilution and for each sampling point, three replicates were made. Additionally, two controls (positive and negative) were maintained to avoid errors due to contamination. After inoculation, culture media were incubated at $37^{\circ} \mathrm{C}$ for 7 days (Aquilanti et al., 2004; Mantilla-Paredes et al., 2009). Observations and descriptions of the macroscopic morphological characteristics i.e. color, border, elevation, texture and shape were made. Finally, the isolation of nitrogen-fixing bacteria was confirmed with staining: bromothymol blue staining and Gram staining (Pérez et al., 2011; Flores- 
Gallegos et al., 2012). The colonies of microorganisms were evaluated by counting viable cells, the $\mathrm{CFU} \mathrm{g}^{-1}$ soil (number of colonies $\times$ dilution factor / volume of inoculum) was determined (Ilyas et al., 2008).

The spatial distribution of potentially nitrogen-fixing bacteria in the Irrigation District of Repelón was determined by generating maps of $\mathrm{CFU} \mathrm{g}^{-1}$ soil with the Surfer program v 23 (developed by Golden Software). In addition, a correlation analysis was performed between the soil physicochemical characteristics and CFU, using the
According to field observations, few soils with agricultural activity were found due to scarce precipitation (Table 1). In the study zone, we found nursery with forest trees of neem (Azadirachta indica) and annual crops (banana, maize, cassava and bean). In the soils 6 and 8, the crops were cassava, maize, banana and bean, and cassava and banana, respectively. Additionally, the sampling sites without agricultural activity, were listed as rest area with vegetal cover (grass). Only in one place, the soil was in preparation for cultivation. Although farmers depend on

Table 1. Description of the land uses during the dry season in the Repelón Irrigation District.

\begin{tabular}{|c|c|c|c|c|c|}
\hline \multirow[b]{2}{*}{ Sampling point } & \multicolumn{5}{|c|}{ Types of plantations } \\
\hline & $\begin{array}{c}\text { Forestry } \\
\text { trees }\end{array}$ & Fruit trees & Annual crops & Rest area & Soil preparation \\
\hline 1. Rest area & + & - & - & + & - \\
\hline 2. Rest area & - & - & - & + & - \\
\hline 3. Rest area & - & - & - & + & - \\
\hline 4. Annual crops & - & - & + & - & - \\
\hline 5. Annual crops & - & - & + & - & - \\
\hline 6. Annual crops & - & - & + & - & - \\
\hline 7. Rest area & - & - & - & - & + \\
\hline 8. Annual crops & - & - & + & - & - \\
\hline 9. Rest area & - & + & - & + & - \\
\hline 10. Rest area & - & - & - & + & - \\
\hline
\end{tabular}

+ Presence, - Absence

Table 2: Physicochemical parameters during the dry season in the soils of the Repelón Irrigation District.

\begin{tabular}{lccccc}
\multicolumn{1}{c}{ Sampling point } & $\mathrm{pH}$ & Texture & Humidity $(\%)$ & Organic matter (\%) & $\begin{array}{c}\text { Total phosphorus } \\
(\mathrm{mg} / \mathrm{kg})\end{array}$ \\
\hline 1. Rest area & 7.26 & sicl & 4.25 & 2.90 & 76.2 \\
2. Rest area & 6.80 & sicl & 3.95 & 5.20 & 90.6 \\
3. Rest area & 6.97 & $\mathrm{c}$ & 5.77 & 4.05 & 94.4 \\
4. Annual crops & 7.23 & $\mathrm{c}$ & 3.71 & 6.00 & 98.5 \\
5. Annual crops & 7.20 & sic & 1.48 & 5.60 & 101.6 \\
6. Annual crops & 7.22 & sic & 4.81 & 5.97 & 113.0 \\
7. Rest area & 6.55 & sic & 0.91 & 3.42 & 106.3 \\
8. Annual crops & 7.20 & sic & 5.99 & 6.45 & 108.5 \\
9. Rest area & 6.44 & $\mathrm{c}$ & 2.43 & 3.83 & 102.8 \\
10. Rest area & 6.41 & $\mathrm{c}$ & 5.61 & 3.58 & 111.3 \\
\hline
\end{tabular}

Soil texture: sicl (silty clay loam), c (clay), sic (silty clay).

Spearman correlation coefficient. In the statistical tests, the differences were significant with a $\mathrm{P}<0.05$. All statistical analyses were performed with the Infostat program (DiRienzo et al., 2012). supply of irrigation water to crop development, during dry season the irrigation district does not function. However, we found some crops where water supply was very low due climatic conditions. Moreover, the surveys confirmed the 
use of chemicals such as Lorsban ${ }^{\mathrm{TM}} 4 \mathrm{E}$ (insecticide), glyphosate (herbicide) and NPK 15-15-15 (fertilizer-Triple $15)^{1}$ when the agricultural activity is active. However, at the time of sampling these were not applied due the areas with the crops were small (approximately $25 \mathrm{~m}^{2}$ ). The farmers communicated that in the dry season, the agricultural activity is low, and they have small areas planted due the irrigation district does not work. In this context, is possible to carry out manual pest control and no high (Murphy et al., 2002). Similarly, the available soil phosphorus was high, emphasizing that points 6 and 10 were characterized by values greater than $110 \mathrm{mg} / \mathrm{kg}$.

In selective culture media, it was observed that in controls (positive and negative) microorganisms did not grow, guaranteeing that the isolated bacteria were in soil samples. The characteristics of colonies of the strain-1 exhibited red color, lanceolate, filamentous and irregular shape, and flat elevation. In contrast, isolated strains-2 the

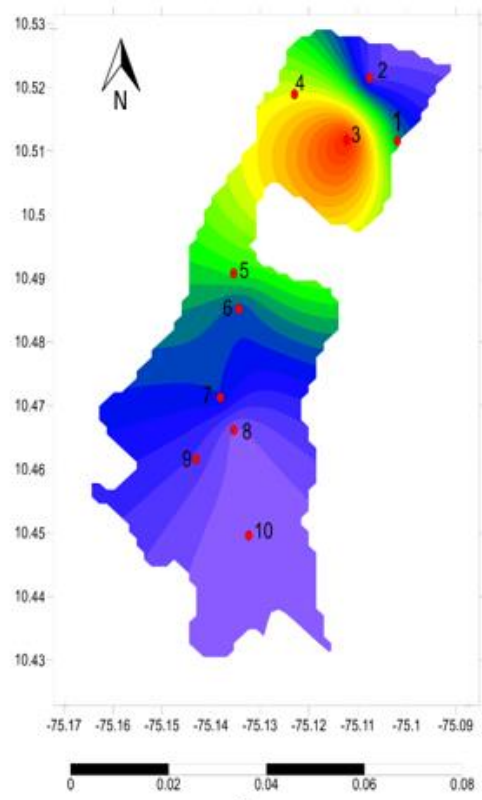

a)

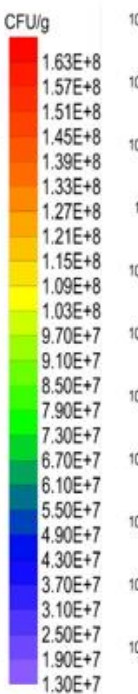

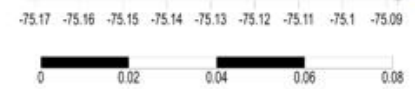

b)
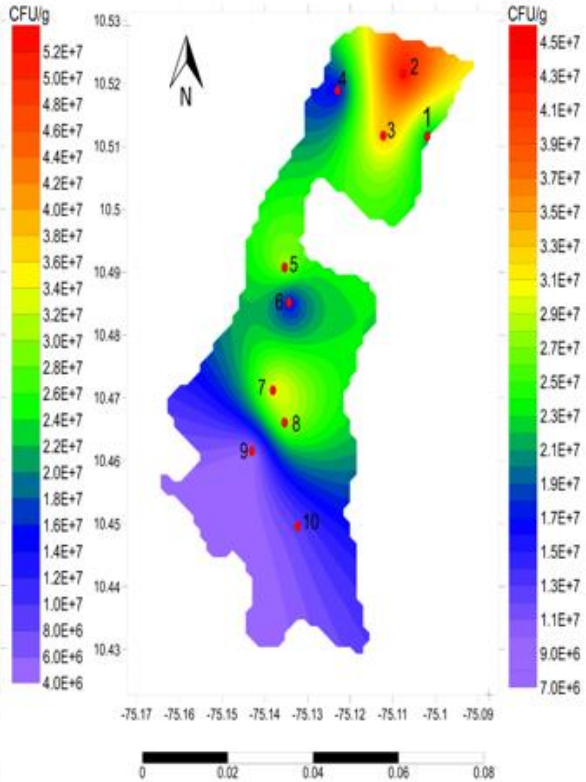

c)

Figure 2. Distribution of potentially nitrogen-fixing bacteria in the Repelón Irrigation District a) Strain-1, b) Strain-3, and c) Strain-2.

fertilization is done because the crops are for themselves and not for commercialization.

Table 2 shows the physicochemical characteristics of the soil for each sampling point. In the study area, the $\mathrm{pH}$ showed variations between slightly acidic (6.4) to slightly alkaline (7.26). Soils presented three textures: silty clay loam, clay and silty clay. On the other hand, soil moisture was generally low, particularly point 7 had the lowest moisture content $(0.91 \%)$; points 3,8 and 10 were characterized by higher moisture contents $(5.79 \%$ on average). The content of organic matter varied in the evaluated soils; point 8 had the highest percentage $(6.45 \%)$ and point 1 exhibited the lowest value (2.90\%); however, according to the soil texture content of this parameter, it is

\footnotetext{
${ }^{1}$ Manufactures name are: Dow (U.S.), Monsanto (U.S.) and Fercon (Colombia), respectively.
}

colonies had white color, irregular shape with filamentous edges, low convex elevation and smooth surface. Finally, in the strains-3 isolates showed yellow, blue-green and cream coloration, lanceolate shape, irregular border, convex elevation and smooth surface. Similarly, the pink staining obtained on gram staining indicated gram-negative bacteria and the yellow staining resulting from the bromothymol blue test allowed us to confirm that the isolated colonies corresponded to potential nitrogen-fixing bacteria.

The $10^{-5}$ dilution was the most appropriate for CFU counting. The total population of strain isolated of agricultural soils is showed in Table 3. The population of isolated bacteria showed variation between the sampled points (Figure 2), comparing the isolated genera, the CFUs varied in the following order strain-1 $>$ strain-3 $>$ strain- 2 . In general, in the south, the $\mathrm{CFU} \mathrm{g}^{-1}$ soil at points 9 and 10 was low. Specifically, average populations were found for the strain- 1 isolates of $2.0 \times 10^{7}$, strain-3 of $1.6 \times 10^{7}$ and 
strain- 2 of $1.1 \times 10^{7} \mathrm{CFU} \mathrm{g}^{-1}$ soil. On the contrary, in the central zone (points 5, 6, 7 and 8) $\mathrm{CFU} \mathrm{g}^{-1}$ varied. The CFU of the strain-1 isolates remained low, with a small increase to the north, thus reaching $3.15 \times 10^{7} \mathrm{CFU} \mathrm{g}^{-1}$ soil (points 7 and 8 ) and $6.55 \times 10^{7} \mathrm{CFU} \mathrm{g}^{-1}$ of soil (points 5 and 6 ). In the strain-3 isolates point 6 was the lowest in this area with $1.9 \times 10^{7} \mathrm{CFU} \mathrm{\textrm {g } ^ { - 1 }}$ soil and point 8 showed the highest population for this group with $5.2 \times 10^{7} \mathrm{CFU} \mathrm{g}^{-1}$ soil. As in the central zone, in the north (points 1, 2, 3 and 4), there was variation in populations. In the north zone, strain-1 (points 3 and 4) and strain-2 (points 2) showed the highest population, with an average of $1.33 \times 10^{8} \mathrm{CFU} \mathrm{g}^{-1}$ soil and $4.40 \times 10^{7} \mathrm{CFU} \mathrm{g}^{-1}$ soil, respectively. In contrast, as for the CFU of the isolates strain-3 in this zone, the lowest populations were observed, on average $6.16 \times 10^{6} \mathrm{CFU} \mathrm{g}^{-1}$ soil. The highest population in south zone was in point 8

\section{(5.26 x $10^{7} \mathrm{CFU} \mathrm{g}^{-1}$ soil).}

The correlation analysis between the soil physicochemical parameters and the CFU of isolates compatible with the nitrogen-fixing bacteria showed a significant correlation $(p \leq 0.05)$ between the available phosphorus and the strain-3, and between the soil texture with the strain-1 and strain-2 (Table 4).

Free living nitrogen-fixing bacteria naturally fertilize the soil by providing a bioavailable form of nitrogen, which can be used by plants. The presence of this type of bacteria in soils also allows the soil to maintain a constant exchange of nutrients and minerals, thus avoiding erosive effects and loss of soil fertility (Philippot and Germon, 2005). In the present investigation, bacterial strains were isolated on nitrogen-free selective media for potential nitrogen-fixing

Table 3. Total population of strain isolated of agricultural soils during the dry season in Repelón Irrigation District.

\begin{tabular}{lccc}
\hline & \multicolumn{2}{c}{ CFU g $^{-1}$ soil } \\
\cline { 2 - 3 } Soil sample & Strain-1 & Strain-2 & Strain-3 \\
\hline 1. Rest area & $6.13 \times 10^{7}$ & $2.06 \times 10^{7}$ & $9.33 \times 10^{6}$ \\
2. Rest area & $2.80 \times 10^{7}$ & $4.40 \times 10^{7}$ & $4.66 \times 10^{6}$ \\
3. Rest area & $1.62 \times 10^{8}$ & $3.40 \times 10^{7}$ & $4.00 \times 10^{6}$ \\
4. Annual crops & $1.04 \times 10^{8}$ & $1.60 \times 10^{7}$ & $6.66 \times 10^{6}$ \\
5. Annual crops & $7.53 \times 10^{7}$ & $2.80 \times 10^{7}$ & $2.86 \times 10^{7}$ \\
6. Annual crops & $5.06 \times 10^{7}$ & $1.60 \times 10^{7}$ & $1.93 \times 10^{7}$ \\
7. Rest area & $4.86 \times 10^{7}$ & $3.06 \times 10^{7}$ & $3.80 \times 10^{7}$ \\
8. Annual crops & $1.66 \times 10^{7}$ & $2.80 \times 10^{7}$ & $5.26 \times 10^{7}$ \\
9. Rest area & $2.93 \times 10^{7}$ & $9.33 \times 10^{6}$ & $1.86 \times 10^{7}$ \\
10. Rest area & $1.33 \times 10^{7}$ & $1.26 \times 10^{7}$ & $1.33 \times 10^{7}$ \\
\hline
\end{tabular}

Table 4. Correlation of $\mathrm{CFU}^{-1}$ soil of nitrogen-fixing bacteria's strain with the physicochemical parameters of the soil.

\begin{tabular}{|c|c|c|c|c|c|c|c|c|c|}
\hline & & Strain-1 & Strain-2 & Strain-3 & $\mathrm{pH}$ & Humidity & $\mathrm{OM}$ & $\mathrm{P}$ available & Texture \\
\hline \multirow[b]{2}{*}{ Strain-1 } & \multirow{9}{*}{$=$} & & & & P-value & & & & \\
\hline & & & & & 0.0804 & 0.5795 & 0.8287 & 0.1615 & 0.0243 \\
\hline Strain-2 & & & & & 0.8799 & 0.9466 & 0.906 & 0.1905 & 0.0038 \\
\hline Strain-3 & & & & & 0.8543 & 0.6032 & 0.6271 & 0.0375 & 0.9716 \\
\hline $\mathrm{pH}$ & & 0.5775 & 0.0550 & -0.0668 & & & & & \\
\hline Humidity & & -0.2000 & 0.0243 & -0.1878 & & & & & \\
\hline $\mathrm{OM}$ & & 0.0787 & 0.0426 & 0.1757 & & & & & \\
\hline $\mathrm{P}$ available & & -0.4787 & -0.4512 & 0.6606 & & & & & \\
\hline Texture & & -0.0261 & 0.8174 & -0.0129 & & & & & \\
\hline
\end{tabular}

$\mathrm{OM}=$ Organic Matter. $\mathrm{P}<0.05$ Significant correlation. 
bacteria. Nitrogen-fixing bacteria commonly inhabit the rhizosphere soil for a long period, colonizing different species of plants with a vast geographical distribution worldwide and other species live independently of the other organisms (Barassi et al., 2007). Soil is considered as the natural medium for the growth of plants and microorganisms however, the physicochemical parameters condition their growth (Horneck et al., 2011).

Different studies have evaluated the correlation of soil physicochemical parameters and microbial populations. The diversity and density of soil bacterial communities are determined by biotic and abiotic factors. In fact, the growth of microbial populations is dependent on soil type, plant species and soil use, and management activities, because these factors influence the structure of bacterial community (Vieira and Nahas, 2005; Horneck et al., 2011; Hamid-Dar et al., 2012). Most crops grow best with a $\mathrm{pH}$ between 6.0 and 8.2 (Horneck et al., 2011). In addition, low-pH soil bacteria decrease their populations and even inhibit $\mathrm{N}$ fixation and nitrification processes. The optimum $\mathrm{pH}$ is 7.0, but ranges 5.0-9.0 are tolerable (NRCS, 2011). In this study, the highest population densities (isolates' strains-1) were found in the northern and central part of the Repelón irrigation district, while the southern part presented the lowest population densities for the three strains analyzed. This could be due to the fact that in these soils the lowest values were found in $\mathrm{pH}$ and organic matter. The variability in $\mathrm{pH}$ could be related to the agricultural activity that has been developed, since the practices of fertilization and pest management using chemicals alter the $\mathrm{pH}$ of soil. In soil samples evaluated, the $\mathrm{pH}$ average was 6.93. Considering this aspect, the $\mathrm{pH}$ of the agricultural soils of the irrigation district of Repelón presents suitable conditions for the establishment of cultures and the populations of microorganisms but the content of organic matter is a factor that is possibly influencing the population density of nitrogen-fixing bacteria.

On the other hand, dry season in the south of the department was associated with the low soil moisture content and high content of organic matter. The majority of soils were rest soils only with vegetal cover (grass) facilitating the accumulation of organic residues that are finally transformed into organic matter. In the same way, the scarce precipitation avoids the washing of the organic matter (higher precipitations in soils without cover are susceptible to water erosion) therefore this is maintained in the soil (Appelhans et al., 2016). In relation with this factor, soil texture influence some soil properties as organic matter retention, microbial biomass and distribution of minerals (Scott and Robert, 2006). In agricultural systems where the increase of the organic matter content has been favored, microbial biomass and the activity of the phosphatase enzymes increased, hence, the mineralization of organic phosphorus increased (Appelhans et al., 2016). It is probable that texture and phosphorus had positive correlation with CFU because they influenced microbial biomass. Similarly, the low agricultural activity associated with non-use of chemical inputs is a factor that favors the soil physico-chemical properties during the dry season.

Although, no genetic identification of isolated strains was reported in this research, the reported literature on soils and similar environmental conditions in the Colombian Caribbean region, could suggest different isolated genera compatible with those found in this evaluation. ObandoCastellanos et al. (2011) in the Cesar department, characterized ashybiotic diazatrophic bacteria associated with eucalyptus (Eucalyptus spp.). Finding that population diversity, among these genera compatible with Azospirillum, Herbaspirillum, Burkholderia, Gluconacetobacter, Azotobacter, Beijerinckia y Derxia showed homogeneous population density when comparing times of rain and drought. This response is possibly associated with edaphic alterations where they modify metabolic functions for the availability of carbon, nitrogen and moisture content. It is probable that some of the strains isolated will be compatible with some of the genera due wide adaptability of these bacteria with environmental conditions. On the other hand, some species of the genus Azotobacter, Azospirillum, Rhizobium and Bradyrhizobium which in addition to being nitrogen-free fixers, are capable of promoting plant growth through solubilization of inorganic phosphates (Fernández et al., 2005). In this evaluation, in soil 8, where the largest population of CFU was present, the total phosphorus content was found among the highest values. This feature is another reason that probably explains the positive correlation between CFU and available phosphorus.

This research represents the first report on microbiological studies in soils of south of the Atlantic department. Emphasizing the importance of the municipality of Repelón as an agricultural pantry, it is imperative to know and identify the microbiota, especially nitrogen fixing bacteria, to reduce the use of inorganic fertilizers and to implement environmentally sustainable agricultural practices, such as bioinoculants that maintain and increase soil fertility, thus improve crop yields by lowering production costs.

\section{References}

Appelhans, S.C., S.M. Benitende, P.A. Barbagelata and M.B. Fontana. 2016. Los cultivos de cobertura y la fertilización afectan el aporte de fósforo microbiano. En A. Degioann (Presidente), $X X V$ Congreso Argentino de la Ciencia del Suelo: 
ordenamiento territorial: un desafío para la ciencia del suelo. Río Cuatro, Argentina.

Aquilanti, F., F. Favillib and F. Clementina. 2004. Comparison of different strategies for isolation and preliminary identification of Azotobacter from soil samples. Soil Biology and Biochemistry 36: 14751483.

Barassi, C.A., R.J. Sueldo, C.M. Creus, L.E. Carrozzi, E. Casanovas and M. Pereyra. 2007. Azospirillum spp. a dynamic soil bacterium favorable to vegetable crop production. Dynamic Soil, Dynamic Plant 1(2): 68-82.

Climate, Data. 2017. National Center for Environmental Information. [Online] Available at: http://es.climate-data.org/location/50352/ [Accessed 1 March 2017].

Dahal, B., G. Nanda-Kafle, L. Perkins and V.S. Brozel. 2017. Diversity of free-living nitrogen fixing Streptomyces in soils of the badliands of South Dakota. Microbiological Research 195: 31-39.

Di-Rienzo, J., F. Casanoves, M. Balzarini, M. GonzalezTablada and C. Robledo. 2012. Universidad Nacional de Córdoba. [Online] Available at: http://www.infostat.com.ar [Accessed 28 February 2017].

Escobar, C., Y. Horna, C. Carreño and G. Mendoza. 2011. Caracterización de cepas nativas de Azotobacter spp. y su efecto en el desarrollo de Lycopersicum esculentum Mill. "tomate" en Lambayeque. Scientia Agropecuaria 2: 36-49.

Fernández, L.A., P. Zalba, M.A. Gómez and M. A. Sagardoy. 2005. Bacterias solubilizadoras de fosfato inorgánico aisladas de suelos de la región sojera. Ciencia del Suelo 23 (1): 31-37.

Ferrera, R and A. Alarcón. 2001. La microbiología del suelo en la agricultura sostenible. Ciencia Ergo Sum 8(2): 175-183.

Flores-Gallegos, A.C., J.C. Contreras-Esquivel and M. Humberto. 2012. Aislamiento e identificación de cepas nativas del suelo mexicano del género Azotobacter. Revista Cientifica de la Universidad Autónoma de Coahuila 4(8): 1-10.

García, S.C. 2011. Bacterias simbióticas fijadoras de nitrógeno. Cuadernos del Tomás 3: 173-186.

Gupta, V.S and M. M. Roper. 2010. Protection of freeliving nitrogen-fixing bacteria within the soil matrix. Soil and Tillage Research 109: 50-54.

Hamid-Dar, G. A. Kamili, R. Nazir, S. Bandh and R. Ahmad-Bhat. 2012. A prelimilary study of colony forming units of bacteria from the soil of Yusmarg Forest, Kashmir Valley India. International Journal of Current Research 4(12): 467-472.
Horneck, D.A., D.M. Sullivan, J.S. Owen and J.M. Hart. 2011. Soil test interpretation guide. [Online] Available at: https://catalog.extension.oregonstate.edu/ec1478 [Accessed 4 March 2017].

IGAC-Instituto Geográfico Agustin Codazzi. 2006. Métodos analíticos del laboratorio de suelos. Bogotá: Imprenta Nacional de Colombia.

IGAC- Instituto Geográfico Agustin Codazzi. 2008. Estudio general de suelos y zonificación de tierras. Departamento del Atlántico. Bogotá: Imprenta Nacional de Colombia.

Ilyas, N., A. Bano and S. Iqbal. 2008. Variation in Rhizobium and Azospirillum strains isolated from maize growing in arid and semiarid areas. International Journal of Agriculture and Biology 10(6): 612-618.

Iturri, L. A and D.E. Buschiazzo. 2016. Light acidification in N-fertilizer losses soils along a limo sequence affected chemical and mineralogical properties in short-term. Catena 139: 92-98.

Mahmood, K. W., N. Yang, Z. Kidhwar, A. Rajputy and A. Arijo. 2006. Study of cellulolytic soil fungi and two nova species and new medium. Journal of Shejiang University Science 7: 459-466.

Mantilla-Paredes, A.J., G.I. Cardona, C.P. Peña-Venegas, U. Murcia, M. Rodríguez and M.M. Zambrano. 2009. Distribución de bacterias potencialmente fijadoras de nitrógeno y su relación con parámetros fisicoquímicos en suelos con tres coberturas vegetales en el sur de la Amazonía colombiana. Revista Biología Tropical 57(4): 915 927.

Martínez-Mera, E., E. Valencia and H. Cuevas. 2016. Evaluación del rendimiento de maíz dulce (Zea mays "Suresweet") con las leguminosas cobertoras mucuna enana (Mucuna pruriens) y crotalaria (Crotalaria juncea "Tropic sun") en un oxisol de Puerto Rico. The Journal of Agriculture of the University of Puerto Rico 100(1): 57-70.

Murphy, S., D. Giménez, L. Muldowney and J. Heckman. 2002. Soil organic matter level and interpretaion. [Online] Available at: http://njaes.rutgers.edu/pubs/publication.asp?pid= FS1136 [Accessed 2 March 2017].

NRCS-National Resources Conservation Service. 2011. Soil quality for environmental matter level and interpretation. [Online] Available at: http://soilquality.org/indicators/soil_ph.html [Accessed 4 March 2017].

Obando-Castellanos, D.M., L.D. Burgos-Zabala, D.M. Rivera-Botia, M.F. Rubiano-Garrido, V.L. DivanBaldani and R.R. Bonilla-Buitrago. 2011. 
Caracterización de bacterias diazotróficas asimbióticas asociadas al eucalipto (Eucalyptus spp) en Codazzi, Cesar (Colombia). Acta Biológica Colombiana 15(3): 107-120.

Olsen, S.R., C.V. Cole, F.S. Watanabe and L.A. Dean. 1954. Estimation of available phosphorus in soils by extraction with sodium bicarbonate. U.S. Department of Agriculture Circ. 939.

Pérez, A., T. Grisales and J. Fuentes. 2011. Determinación de morfotipos nativos de Rhizobium asociados a la leguminosa Teramnus volubilis $\mathrm{Sw}$ en fincas ganaderas en el municipio de Tolú en el departamento de Sucre. Revista Colombiana de Ciencia Animal 3(1): 62-89.

Philippot, L and J.C. Germon. 2005. Contribution of bacterial to initial input and cycling of nitrogen in soils. P. 159-176. In F. Buscot and A. Varma. (Ed.) Microorganisms in soils: roles in genesis and functions. Springer, New York.
Scott, J and J. Robert. 2006. Soil texture and nitrogen mineralization potential across a riparian toposequence in a semi-arid savanna. Soil Biology and Biochemestry 38(6): 1325-1333.

Torres-Bejarano, F., J. Padilla-Coba, C. Rodríguez-Cuevas, H. Ramírez-León and R. Cantero-Rodelo. 2016. La modelación hidrodinámica para la gestión hídrica del embalse El Guájaro, Colombia. Revista Internacional de Métodos Numéricos para Cálculo y Diseño de Ingeniería 32(3): 163-172.

Vieira, F.C and E. Nahas. 2005. Comparision of microbial numbers in soils by using various culture media and temperatures. Microbiological Research 3(1): 62-89.

Walkley, A and I.A. Black. 1934. An examination of Degtjareff method for determining soil organic matter, and proposed modification of the chromic acid tritation method. Soil Science 37:29-38. 